\title{
Evolution of fluvial system and reconstruction of paleohydrology of late Cenozoic Siwalik Group, related to tectonic uplift of Himalaya and climatic change, Kankai River section, east Nepal Himalaya
}

\author{
Prakash Das Ulak \\ Department of Geology, Tri-Chandra Campus,Tribhuvan University, Kathmandu, Nepal \\ (Email: prakashulak@yahoo.com)
}

\begin{abstract}
This paper focuses on evolution of the fluvial system in the late Cenozoic Siwalik Group along the Kankai River section of East Nepal. The Siwalik Group lies on the southern flank of the Himalaya and composed of molasse sediments, which were derived from upheaval of the Himalaya. On the basis of lithology, assemblage of sedimentary structures and sediment body architectures, seven facies associations (FA1 to FA7) are recognized in the Kankai River section, East Nepal Himalaya. These recognized facies associations are closely related to each lithostratigraphic units of the area (Ulak 2009). The lower and upper members of the Lower Siwaliks are the products of the fine-grained meandering and flood flow-dominated meandering systems, respectively. The lower, middle and upper members of the Middle Siwaliks are interpreted as the deposits of the sandy meandering, deep sandy braided and shallow braided systems, respectively whereas the lower and upper members of the Upper Siwaliks are the products of the gravelly braided and debris flow-dominated braided systems, respectively. Paleohydrological characteristics and its evolutional changes of the group have been estimated by using grain diameter and thickness of finingupward fluvial successions. The paleohydrology suggests an increase in of flow velocity, channel slope gradient, and discharge of the fluvial system. Paleovelocity varies from $0.19 \mathrm{~m} / \mathrm{s}$ to $5.31 \mathrm{~m} / \mathrm{s}$ paleochannel gradient and paleodischarge changes from $6.67 \times 10^{-5}$ to $2.97 \times 10^{-4} \mathrm{~m} / \mathrm{m}$ and $10^{1}$ to $10^{4} \mathrm{~m}^{3} / \mathrm{s}$, respectively in stratigraphic upward. The progressively changes in the paleohydrology reflect the southward propagation of thrust activities, caused upheaval of the Himalaya.
\end{abstract}

Keywords: Paleohydrology, Siwalik Group, tectonic uplift, climate, Kankai River

Received: 20 September 2015

Revision received: 27 February 2016

\section{INTRODUCTION}

The Siwalik Group is delimited by the Lesser Himalaya to the north and Indo-Gangetic Plain to the south and located between the Main Boundary Thrust (MBT) and the by the Main Frontal Thrust (MFT). This group is exposed in the southern frontal hilly areas called Churia Hills and is also called the Churia Group instead of the Siwalik Group and is comprised of fluvial sediments, which were deposited as a result of Neogene tectonics of the Himalaya (Parkash et al. 1980; Nakayama and Ulak 1999; Ulak and Nakayama 2001). As a whole, the stratigraphic succession shows coarsening upward.

Lithostratigraphy of the Siwalik Group of the Nepal Himalaya has been established by Auden (1935); Glennie and Ziegler (1964); Hagen (1969); Yoshida and Arita (1982); Tokuoka et al. (1986); Corvinus and Nanda (1994); Sah et al. (1994); Dhital et al. (1995); Ulak and Nakayama (1998); Ulak (2004); Ulak (2009) and others. The Siwalik Group is subdivided traditionally into three units, namely, the Lower, Middle, and Upper Siwaliks, in ascending order. But locally, two- to six-fold classifications of the Siwalik rocks are also acceptable. This study also follows the three-fold subdivision of the Siwalik Group. Studies on evolution of the fluvial styles have been studied in the Siwalik Group by Nakajima (1982); Willis (1993); Hisatomi and Tanaka (1994); Zaleha (1997); Khan et al. (1997); Ulak and Nakayama (1998); Nakayama and Ulak (1999); Ulak and Nakayama (2001) and Ulak (2004). These studies have shown that the meandering system was appeared at first during evolution of the Siwalik basin and then it was changed into the braided system to gravelly braided system due to upheaval of Himalaya as well as increment in the sediment supply.

The paleohydrological reconstruction of the Siwalik succession from Nepal Himalaya has been studied by Ulak (2009); Ulak (2006); Ulak and Nakayama (2003); Ulak (2002); Ulak and Nakayama (2002); Ulak and Nakayama (2001); Ulak (2001); Ulak and Nakayama 1(999) show progressively increasing towards older to younger sequences.

Evolution of the fluvial system and paleohydrological reconstruction of the Siwalik Group, related to tectonic uplift of Himalaya and climatic change, Kankai River section, East Nepal have not been carried out. However the present paper deals relation between sedimentary environmental changes of fluvial systems on the basis of the facies associations and estimation of paleohydrology and its relation to the upliftment of Himalaya and climatic change. 


\section{LITHOSTRATIGRAPHY}

The lithostratigraphy of the study area is summarized in Table 1 and Figures 1 and 2. Based on the lithology and grain size, the group is subdivided into the Lower, Middle and Upper Siwaliks, in ascending order (Ulak 2009). The Lower and Upper Siwaliks are subdivided into the lower and upper members, respectively whereas the Middle Siwaliks is into the lower, middle and upper members, respectively. The Central Churia Thrust (CCT) in this study area has been divided into north and south belts (Fig. 1).

The Lower Siwalik is subdivided into the lower and upper members based on the thickness of sandstone and mudstone beds and grain size of sandstone. The lower member of the Lower Siwaliks is characterized by the dominance of mudstone over sandstone to roughly equal proportion of sandstone and mudstone. This unit is characterized by very fine- to fine-grained, greenish-grey sandstone interbedded with bioturbated, variegated mudstone. Mudstone beds range 1 to $5 \mathrm{~m}$ thick whereas sandstones are 1 to $3 \mathrm{~m}$ thick. Mudstone frequently includes concretions. Sandstones are highly indurated due to presence of calcareous cementing materials. This member attains about $210 \mathrm{~m}$ thick. The upper member is defined by alternating beds of medium- to coarse-grained sandstone and variegated to dark grey mudstone, in which sandstone are thicker than mudstone beds. Sandstone shows "pepper and salt" appearance in the top of the member. This member reaches about $450 \mathrm{~m}$ in total thickness.

Based on grain size of sandstone, Middle Siwalik is subdivided into the lower, middle and upper members, in ascending order. The lower member is represented by mediumto coarse-grained "pepper and salt" appearance sandstone with dark grey to black mudstone. Mudstone beds are comparatively thinner and less variegation developed than one of the Lower Siwaliks. Thickness of coarse-grained sandstones ranges from 5 to $15 \mathrm{~m}$ whereas muddy sandstone and mudstones ranges from 1 to $2 \mathrm{~m}$. Fining upward fluvial succession shows from coarse sandstones to mudstone are distinct, an individual succession is 7 to $20 \mathrm{~m}$ thick. This unit is about $340 \mathrm{~m}$ thick. The middle member comprises thick-bedded, coarse- to very coarse-grained, "pepper and salt" sandstone and grey mudstone. Sandstone are less indurated and commonly shows multistoried. The multistoried sandstone beds are 6 to $30 \mathrm{~m}$ thick whereas mudstone beds are 2 to $3 \mathrm{~m}$ thick. Obvious fining upward ranges 10 to $35 \mathrm{~m}$ thick. This unit attains about $600 \mathrm{~m}$ in total thickness. The upper member is distinguished by very coarse-grained to pebble bearing sandstone and reaches $2,100 \mathrm{~m}$ in total thickness. Sandstone is loose and multistoried in nature. Cobbles and pebbles in sandstone are rounded to subrounded which are originated from the Lesser Himalayan terrain. Each fining-upward succession is 5 to $15 \mathrm{~m}$ thick.

The lower member of the Upper Siwaliks is represented by well-sorted, pebble- and cobble-sized conglomerate associated with reddish-brown sands and dark grey muds. The clasts of conglomerate are subrounded to sub angular in shape and show slight increase in their size toward the stratigraphic younger succession. Imbrications of clasts are also observed in all horizons. Conglomerate bed is 5 to $20 \mathrm{~m}$, while mudstone and sandstone beds are 50 to $150 \mathrm{~cm}$ thick. Fining-upward successions are frequently observed and their thickness is about 5 to $25 \mathrm{~m}$. The lower member is about $1,100 \mathrm{~m}$ in total thickness. The upper member is characterized by poorly sorted, loose, boulder-sized conglomerate with grey sands and muds. A typical characteristic of this unit is presence of Siwaliks sandstone boulders. Fining-upward successions are rarely developed. A complete fining-upward succession is typically 7 to $10 \mathrm{~m}$ in thickness.

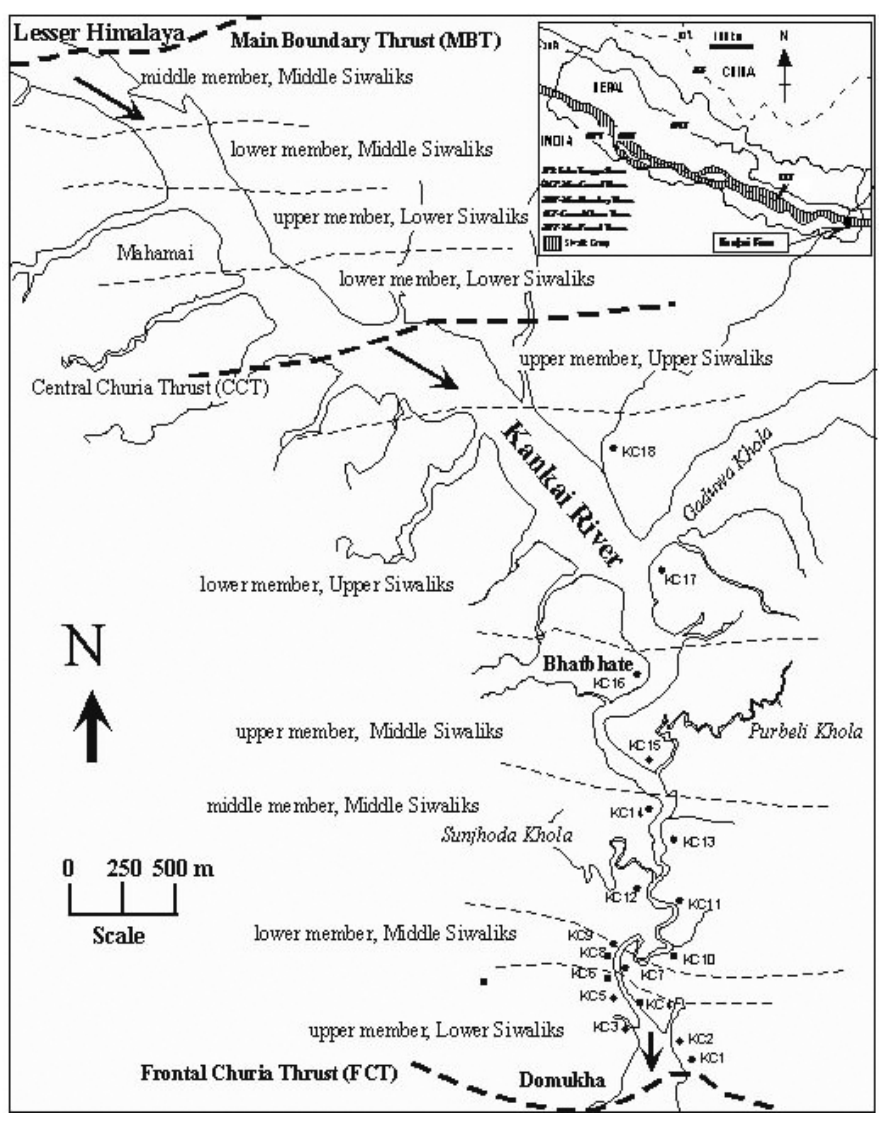

Fig. 1: Geological map of the Kankai River area, Siwalik Group, east Nepal (Ulak 2009).

\section{SEDIMENTARY FACIES ANALYSIS}

Representative detailed columnar sections, which show typical fluvial autogenetic fining upward successions of the Siwalik Group along the Kankai River were prepared and studied in the field. (Fig. 2). Categorization of the facies associations was based on nature of lithology, assemblage of sedimentary structures and sediment body architectures. Miall (1996) lithofacies code and architectural elements were followed in this work. Dominant and minor lithofacies types and characteristic architectural element are shown in Table 2. 

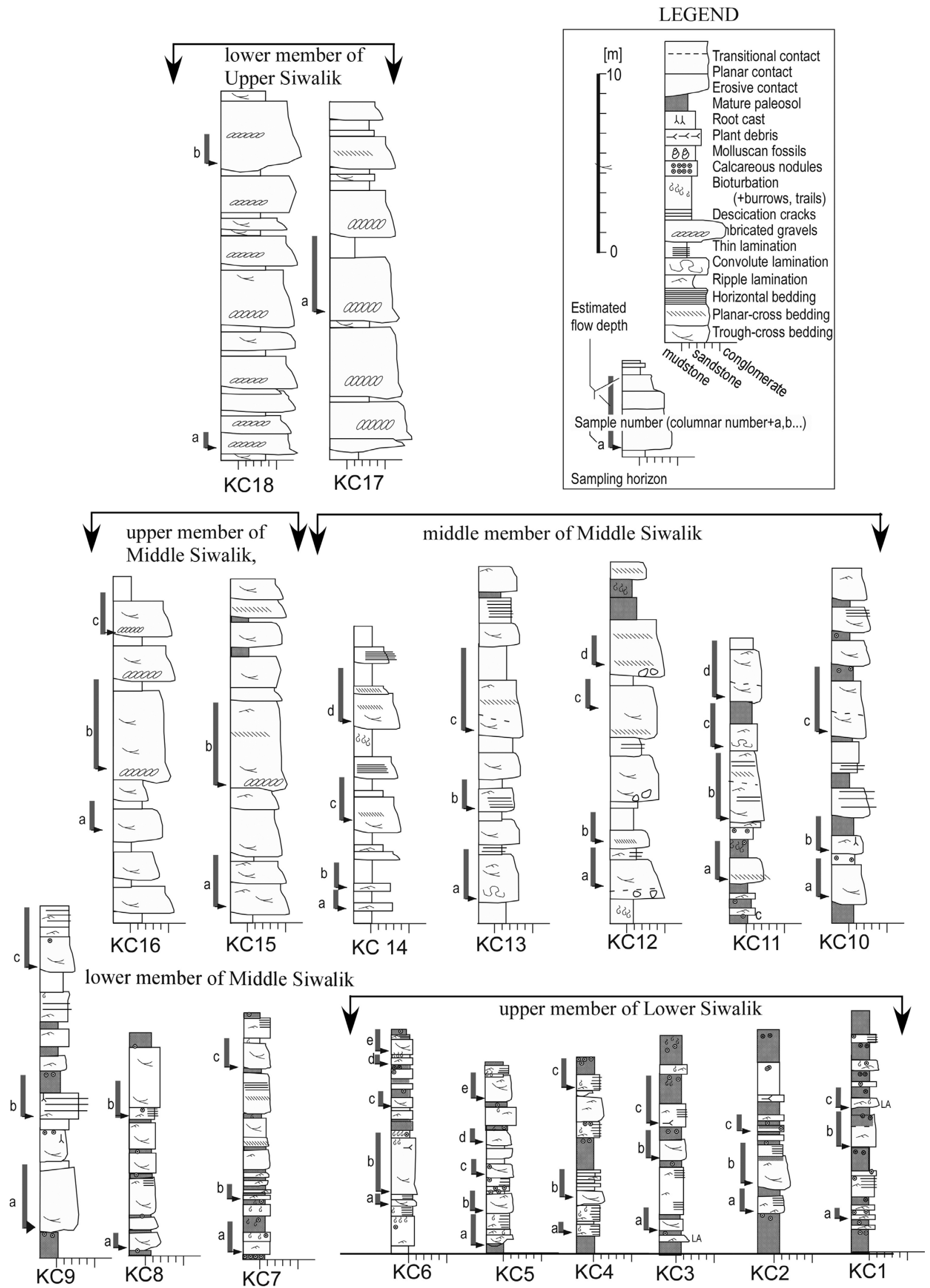

Fig. 2: Columnar log sections and sampling points of the Kankai River section Siwalik Group, east Nepal. 


\section{FA1-Facies Association}

The FA1-Facies association is represented by dominance of bioturbated, thick-bedded mudstone (Fm, Fr, Fsm; 0.5 to $3 \mathrm{~m}$ thick) interbedded with fine-grained, greenish-grey, calcareous sandstone ( $\mathrm{Sr}, 0.2$ to $2.5 \mathrm{~m}$ thick) and sometimes thinly laminated mudstone (Fl) beds. Each fining-upward succession start from trough cross-bedded sandstone $(\mathrm{St})$ at base to mudstone at top are apparent, averages about 7 to 10 $\mathrm{m}$ thick. This facies association is also characterised by the presence of paleosols ( $\mathrm{P} ; 1$ to $3 \mathrm{~m}$ thick) at the top of the fining upward sequence. The mudstones as well as the fine-grained sandstones are highly variegated. Sandstone beds have a sheetlike geometry, and are commonly composed of slightly muddy sands. Sandstone beds are massive and occasionally rippled. Trough-cross bedded and ribbon-shaped sandstone beds are rare. Some of these sandstones occur as broad, isolated or overlapping ribbons with lateral accretionary architecture. Lateral accreted architectures are also found in thick sandstone beds in the area. Calcareous nodules are well observed on the upper surfaces of fine-grained sandstone beds, and also occasionally occur in mudstone. The nature of basal contact surface of sandstone beds with the underlying sequence is flat or slightly eroded. Ripple laminations, raindrop imprints, mudcracks and trace fossils are commonly preserved in fine- to medium-grained sandstone beds. The facies association- FA1 is developed in the lower member of the Lower Siwalik.

\section{Interpretation}

The facies association (FA1) is thought to be product of a fine-grained meandering system due to presence predominance of bioturbated, variegated and thick-bedded mudstone beds (Fm), presence of calcareous nodules (P), abundance of trace fossils in fine-grained sandstone beds. Significant amount of paleosols (P), imprint of raindrops and mud cracks suggest the presence of extensive flood plain deposits of the meandering river and considered as the sediments were exposed for a long time on the flood plain. Presence of greater amount of mudstone (Fm, Fr, Fsm) than sandstone beds and lateral accretionary architectures of sandstone are interpreted as indication of the existence of high sinuosity meandering river system carrying a great amount of suspended load. The rippled ( $\mathrm{Sr}$ ) and sheetlike sandstone beds interbedded within mudstone beds (Fm, Fl) represent crevasse splay deposits. Occurrence of the mudstone at the top of the fining-upward succession represents deposition took place at calm to stagnant condition (Nakajima 1982).

\section{Facies Association (FA2)}

The facies association (FA2) is recognized by the presence of medium- to coarse-grained, grey sandstone (St, Sp, Sr) interbedded with thinly layered muddy sandstone (Sh) and variegated to dark grey mudstone (Fm, Fl, Fsm). This facies association is also represented frequently by multiple accumulated sequences of mudstone and sandstone and preserve ripple lamination $(\mathrm{Sr})$ including climbing ripples. The sandstone amount is comparatively more than mudstone. Fine-grained sandstone beds are generally very thin $(0.5$ to $2 \mathrm{~m}$ thick), and massive in places. Fine- grained sandstone beds have a sheet-like geometry, are massive to rippled, and occasionally grade into overlying mudstones or grade from underlying mudstones. The coarse-grained beds of sandstone reach up to $4 \mathrm{~m}$ in thickness and show trough cross-stratifications (St) are frequently ribbon-shaped with lateral accretionary architecture. The fine-grained sandstone beds are commonly multi-storied, whereas the coarser ones are frequently isolated. Thickness of the fine sandstone (Sh) beds vary between 10 and $70 \mathrm{~cm}$, some of the coarser sandstone beds are about $10 \mathrm{~m}$ thick, whereas mudstone beds are 1 to $2 \mathrm{~m}$ thick. Fining upward succession from the coarser sandstone to mudstone is clear. The thickness of such successions is 7 to $30 \mathrm{~m}$ beginning from coarse-grained sandstone to mudstone. The basal contact surface of sandstone beds is commonly slightly eroded to flat. Bioturbation and paleosols are less than those in the FA1- facies association. FA2-facies association is found in the upper member of the Lower Siwalik.

\section{Interpretation}

The facies association (FA2) is interpreted to belong to a flood flow-dominated fine-grained meandering river system. Repeated occurrence of thin layers of muddy sandstone (Sh) beds within fine to coarse sandstone is interpreted to have formed by successive flood flows. Laminated sandy mudstone (Fl) and fine-grained sandstone (Sr) represent depositions from suspension and weak currents. Climbing ripples indicate gradual decrease in the velocity of flood flow. Coarsegrained sandstone (St) with lateral accreted architectures reflect bedload deposits of the meandering channels, whereas sheet-like geometry of finer grained sandstone beds reflect their origin to the vertical aggradation by flooding. Vertical lithological variability is susceptible to a small change in depositional process. Interbedded paleosols $(\mathrm{P})$ with laminated fine- to medium-grained sandstone beds indicate the seasonal or long-term drying out on the flood plain.

\section{Facies Association (FA3)}

The facies association (FA3) is represented by thick-bedded, medium- to coarse-grained sandstone associated with dark grey mudstone and muddy sandstone. Dark grey mudstone (Fl, Fsm) beds are thin frequently subordinates to sandstone. Medium- to coarse-grained sandstone beds represent channel deposits and have trough cross-stratification (St), minor planar cross-stratification (Sp), which occasionally forms both lateral and down accretional architectures. The muddy sandstones, commonly interbedded within the mudstones, have a multistoried, sheet-like geometry, and some of them contain ripples (Sr). Thinly layered muddy sandstone (Sh) beds interbedded with mudstone with sheet-like geometry sometimes exhibit ripples, as well as convolute beddings. The basal contact of each fluvial succession is erosional. Sandstone beds are generally 1 to $3 \mathrm{~m}$ thick and increase up to $5 \mathrm{~m}$ at some places, and mudstone beds are 0.5 to $2 \mathrm{~m}$ in thickness. The fining upward fluvial successions ( 2 to $5 \mathrm{~m}$ thick) are conspicuous and common. The lower member of the Middle Siwalik exhibits the facies association (FA3). 
Table 1: Summary of the lithostratigraphy of the Siwalik Group, Kainkai River area, east Nepal (Ulak 2009)

\begin{tabular}{|c|c|c|c|}
\hline \multicolumn{2}{|l|}{ Stratigraphy } & \multirow{2}{*}{$\begin{array}{l}\text { Thickness } \\
\text { (m) } \\
450+\end{array}$} & \multirow{2}{*}{$\begin{array}{l}\text { Lithological characteristics } \\
\text { Poorly-sorted, matrix-supported boulder-sized, loose conglomerates } \\
\text { and lenses of sands. Sandstone boulders are derived from the Siwalik } \\
\text { Group itself. }\end{array}$} \\
\hline \multirow{2}{*}{ Upper Siwalik } & Upper member & & \\
\hline & Lower member & 1100 & $\begin{array}{l}\text { Well-sorted, clast-supported, cobble-pebble-sized conglomerates. } \\
\text { Almost clasts of conglomerate are from the Lesser Himalayan terrain. }\end{array}$ \\
\hline \multirow{3}{*}{ Middle Siwalik } & Upper member & 2100 & $\begin{array}{l}\text { Thick-bedded, coarse- to very coarse-grained, friable, "pepper and } \\
\text { salt" sandstone with pebbly sandstone. }\end{array}$ \\
\hline & Middle member & 600 & $\begin{array}{l}\text { Thick-bedded, coarse- to very coarse-grained, "pepper and salt" } \\
\text { sandstone withdark grey mudstone. Sandstones are moderately } \\
\text { indurated (sst }>>\text { mst). }\end{array}$ \\
\hline & Lower member & 340 & $\begin{array}{l}\text { Medium- to coarse-grained sandstone with dark grey mudstone. } \\
\text { "Pepper and salt"sandstone are found in which the amount of biotote } \\
\text { flakes are less (sst>mst). }\end{array}$ \\
\hline \multirow[t]{2}{*}{ Lower Siwalik } & Upper member & 210 & $\begin{array}{l}\text { Medium- to coarse-grained, grey sandstone alternates with bioturbated, } \\
\text { variagated to dark grey mudstone. "pepper and salt" sandstone are } \\
\text { rarely found (sst>mst). }\end{array}$ \\
\hline & Lower member & $500+$ & $\begin{array}{l}\text { Fine-grained, calcareous, greenish-grey sandstone interbeds with } \\
\text { bioturbated, variegated mudstone (mst }>>\text { sst). }\end{array}$ \\
\hline
\end{tabular}

Table 2: Description and interpretation of the FA-facies association along the Kankai River section, east Nepal.

\begin{tabular}{|c|c|c|c|c|c|c|}
\hline $\begin{array}{l}\text { Facies } \\
\text { association }\end{array}$ & $\begin{array}{l}\text { Dominant } \\
\text { lithofacies } \\
\text { types* }\end{array}$ & $\begin{array}{l}\text { Minor } \\
\text { lithofacies } \\
\text { types* }\end{array}$ & $\begin{array}{l}\text { Characteristic } \\
\text { architectural } \\
\text { element** }\end{array}$ & $\begin{array}{l}\text { Dominant } \\
\text { geometry }\end{array}$ & $\begin{array}{l}\text { Stratigraphic units } \\
\text { of the Kankai River } \\
\text { area east Nepal }\end{array}$ & $\begin{array}{l}\text { Depositional } \\
\text { environment }\end{array}$ \\
\hline FA1 & $\begin{array}{l}\mathrm{P}, \mathrm{Fr}, \mathrm{Fm}, \mathrm{Sr}, \\
\mathrm{Fl}, \mathrm{Fsm}\end{array}$ & $\mathrm{St}, \mathrm{Sr}$ & $\mathrm{FF}, \mathrm{SB}, \mathrm{LA}>\mathrm{LS}$ & $\begin{array}{l}\text { sheet, } \\
\text { ribbon }\end{array}$ & $\begin{array}{l}\text { Lower member of the } \\
\text { Lower Siwalik }\end{array}$ & $\begin{array}{l}\text { Fine-grained } \\
\text { meandering system }\end{array}$ \\
\hline FA2 & $\begin{array}{l}\text { St, Sr, Fl, Fm, } \\
\text { Fr, P }\end{array}$ & $\begin{array}{l}\text { Fsm, Ss, } \\
\mathrm{Sp}, \mathrm{Sh}\end{array}$ & $\mathrm{LA}, \mathrm{FF}, \mathrm{SB}>\mathrm{DA}$ & $\begin{array}{l}\text { sheet, } \\
\text { massive }\end{array}$ & $\begin{array}{l}\text { Upper member of the } \\
\text { Lower Siwalik }\end{array}$ & $\begin{array}{l}\text { Flood flow-dominated } \\
\text { meandering system }\end{array}$ \\
\hline FA3 & $\begin{array}{l}\text { St, Sr, Sp, Ss, } \\
\text { Sh }\end{array}$ & $\begin{array}{l}\text { Fsm, Fl, } \\
\text { P, Gt }\end{array}$ & $\mathrm{DA}, \mathrm{LA}, \mathrm{FF}, \mathrm{SB}$ & sheet & $\begin{array}{l}\text { Lower member of the } \\
\text { Middle Siwalik }\end{array}$ & $\begin{array}{l}\text { Sandy meandering } \\
\text { system }\end{array}$ \\
\hline FA4 & $\begin{array}{l}\text { St, Sr, Sp, Ss, } \\
\text { Sh }\end{array}$ & $\begin{array}{l}\text { Fl, Fsm, } \\
\text { Gt, P }\end{array}$ & $\begin{array}{l}\text { SB, DA } \\
>\text { LA, HO, FF }\end{array}$ & $\begin{array}{l}\text { sheet, } \\
\text { ribbon }\end{array}$ & $\begin{array}{l}\text { Middle member of } \\
\text { the Middle Siwalik }\end{array}$ & $\begin{array}{l}\text { Deep sandy braided } \\
\text { system }\end{array}$ \\
\hline FA5 & $\begin{array}{l}\mathrm{St}, \mathrm{Sp}, \mathrm{Fms}, \\
\mathrm{Sr}\end{array}$ & $\mathrm{Fl}, \mathrm{P}, \mathrm{C}$ & $\begin{array}{l}\text { DA, FF, SB } \\
>\text { LA }\end{array}$ & sheet & $\begin{array}{l}\text { Upper member of the } \\
\text { Middle Siwalik }\end{array}$ & Shallow braided system \\
\hline FA6 & $\mathrm{Gp}, \mathrm{Gt}, \mathrm{Gh}$ & $\begin{array}{l}\mathrm{St}, \mathrm{Ss}, \\
\mathrm{Sr}, \mathrm{Fms}, \\
\mathrm{Gmm}\end{array}$ & $\begin{array}{l}\text { GB } \\
>\mathrm{SB}, \mathrm{DA}, \mathrm{HO}\end{array}$ & sheet & $\begin{array}{l}\text { Lower member of the } \\
\text { Upper Siwalik }\end{array}$ & $\begin{array}{l}\text { Gravelly braided } \\
\text { system }\end{array}$ \\
\hline FA7 & $\begin{array}{l}\text { Gp, Gh, } \\
\text { Gcm, mm, } \\
\text { Gmg }\end{array}$ & $\begin{array}{l}\text { Gt, St, Ss, } \\
\text { Sr, Fms }\end{array}$ & $\begin{array}{l}\mathrm{SG}, \mathrm{GB} \\
>\mathrm{DA}\end{array}$ & sheet, & $\begin{array}{l}\text { Upper member of the } \\
\text { Upper Siwalik }\end{array}$ & $\begin{array}{l}\text { Debris flow-dominated } \\
\text { braided system }\end{array}$ \\
\hline
\end{tabular}

*Classification from Miall $(1977,1996)$. ** CH recognised in all facies associations. Classification from Miall (1985, 1996) mstmudstone; sst-sandstone; congl-conglomerate.

\section{Interpretation}

The facies association (FA3) is also considered to be result of a sandy meandering river system with flood flow dominant deposits. The evidence for this type of fluvial system is the existence of lateral accreted cross-stratified sandstone and multiple accumulated muddy sandstone beds. The former beds suggest the deposits by bedload of high sinuosity channel flow, while the latter beds are formed by crevasse splay deposits. The essential difference between the FA2 and FA3-facies associations are in the predominance of finely laminated mudstone beds $(\mathrm{Fl})$ and fine rippled sediments ( $\mathrm{Sr})$ in FA 2 while FA3 facies is characterised by predominance of trough stratified (St) and rippled ( $\mathrm{Sr}$ ) sandstone beds. This indicates a slight increase in discharge of the rivers from FA2 to FA3 facies. 


\section{Facies Association (FA4)}

The facies association (FA4) is characterized by the presence of thick-bedded, coarse- to very coarse-grained sandstone, sandstone and dark grey mudstone beds. Here the proportion of mudstone beds are less than in FA3. Largescaled trough cross- stratification $(\mathrm{St})$ is well preserved in the sandstone beds. These multistoried beds generally have sheet like geometry on an outcrop scale, although down accretions and lateral accretions with uncompleted ribbon shapes are also recognized. The coarse- to very coarse-grained sandstone and pebbly sandstone beds sometimes form downstream accretionary and lateral accretionary architectures. The thickness of individual sandstone beds ranges from 1 to 5 $\mathrm{m}$, and pebbly sandstone beds are about 0.5 to $1 \mathrm{~m}$. Pebbly sandstone beds have sheet-like geometry. Rounded to subrounded pebbles in these sandstone beds are derived from Lesser Himalayan rocks. Majority of the clasts are quartzite with 1 to $5 \mathrm{~cm}$ in diameter. The maximum size of mud clasts found in sandstone beds is about $15 \mathrm{~cm}$ along its long axis. The fining upward sequences (5 to $15 \mathrm{~m}$ thick) are distinct, which starts from pebbly sandstone bed with basal erosional surface. The thickness of bedload sediments consisting of coarse- to very coarse-grained sand and pebbly sand which forms the basal parts of the fining upward sequences commonly ranges between 4 and $10 \mathrm{~m}$. The facies association (FA4) is developed in the middle member of the Middle Siwalik.

\section{Interpretation}

The FA4-facies association is considered to have deposited by a deep sandy braided river system evidenced by the great volume of bedload sandstone with downstream and lateral accretionary architecture. Existence of intraformational mudclasts at the bottom of each fluvial succession suggests bank-cut materials produced during lateral migration of the channel. Commonly occurring thick fining upward sequences and presence of thick units of sandstone (St, Sp) and pebbly sandstone beds with erosional bases suggest the existence of deep channel flows.

\section{Facies Association (FA5)}

The FA5-facies association is identified by the presence of thick-bedded, coarse- to very coarse-grained sandstone beds with subordinate pebbly sandstone and dark grey mudstone beds. FA5-facies components are essentially similar to those of facies (FA4) except in the presence of trough stratified gravel (Gt) beds and occurrence of thicker sandstone and pebbly sandstone beds. Coarse- to very coarse-grained sandstone and pebbly sandstone beds are trough (St) and planar (Sp) cross-stratified and show multiple accumulation. Some sandstone beds exhibit planar cross-bedded, and multistoried, others are trough cross-bedded and multi-storied. Most multi-storied sandstones have sheet-like geometry, in which down accretionary architectures are frequently observed. The sandstone and pebbly sandstone beds invariably shows erosional bases. Ripple laminated and plane-stratified sandstone beds are frequently observed in the upper part of thick-bedded sandstones. However, plane-stratified beds are frequently associated with large scale cross-stratification, and are rarely combined with ripple beds. Downstream accretionary architecture is occasionally found in these units. Paleocurrent directions show little dispersion. Typical characteristic feature of this facies association is the rare occurrence of weakly developed fining upward succession. When present, the thickness of each fining upward succession from coarsegrained sandstone or pebbly sandstone to mudstone ranges from 5 to $10 \mathrm{~m}$. This facies association is found in the upper member of the Middle Siwalik.

\section{Interpretation}

The facies association (FA5) is developed by a shallow sandy braided river system. Less distinct fining upward successions, sheet-like geometry of sandstone and pebbly sandstone, the development of planar stratification (Sp) imply a shallower fluvial system. Multiple accumulations of planar cross-stratified coarse-grained sandstone beds with a small dispersion in paleocurrent directions are the evidence of the shallow sandy braided river system. The combination of largescale cross-stratification and plane-stratification indicates that the beds must have formed under upper flow regime.

\section{Facies Association (FA6)}

The facies association (FA6) is typified by presence of thick-bedded, clast supported and well-sorted conglomerate subordinate lenses of reddish brown sandstone and dark grey mudstone. Almost all the clasts are pebble- or cobble-sized, rounded to subrounded in shape and derived from Lesser Himalayan terrain. Planar cross-stratifications (Gp) are well preserved but trough cross-laminations (Gt) are poorly developed in the conglomerates. Imbrication of the clasts is apparent. The conglomerates are 5 to $15 \mathrm{~m}$ thick, while the interbedded sandstone and mudstone beds range from 0.5 to $1 \mathrm{~m}$ in thickness. Fining upward sequence is indistinct due to the presence of numerous erosional surfaces. The paleocurrent directions measured from the imbricated gravels do not show scatter. FA6-facies association is well developed in the lower member of the Upper Siwalik.

\section{Interpretation}

The facies association (FA6) suggests that the sediments were deposited by gravelly braided river system as evidenced by the presence of widespread bedload gravel clasts, and uniformity in paleocurrent direction. Numerous erosional surfaces and predominance of conglomerate over other rock types may imply that the river system was relatively shallow and/or having unstable channels.

\section{Facies Association (FA7)}

Facies association (FA7) is the coarsest facies association 
composed of dominance of poorly sorted angular to subangular shaped, muddy matrix supported boulder conglomerates (Gms), have loose packing, and occasionally inverse grading. Imbrications are not prominent. Many of boulder-sized sandstones are derived from the Lower Siwailks other clasts are derived from the Lesser and Higher Himalayan rocks. Generally subrounded to subangular shaped clast supported well sorted pebble- to cobble conglomerates $(\mathrm{Gm})$ similar to those in FA6 subordinate with grey sandstones $(\mathrm{St})$ and dark grey to brownish grey mudstone $(\mathrm{Fm})$ with no sharp bases were observed. Gm facies have sheet geometry. The conglomerate beds range from 5 to $12 \mathrm{~m}$ in thickness, whereas sandstone and mudstones are less than $2 \mathrm{~m}$ thick. Upward fining successions are cryptic, but may be less than $20 \mathrm{~m}$ thick. Commonly increased clast sizes are directly observed toward top of its stratigraphic position. The maximum size of the sandstone boulders is upto $1 \mathrm{~m}$ in its long axis diameter whereas generally the clast sizes are 15 to $25 \mathrm{~cm}$ in its diameter. The facies association associates in the upper member of the Upper Siwalik.

\section{Interpretation}

Poorly sorted character and clast supported boulder conglomerates (Gms facies), muddy matrix and disorganized clasts arrangement or an inverse grading are thought to be rapid deposition took place in proximal fluvial channels subjected to the debris flows. Inverse graded, massive conglomerate beds are interpreted as the sieve deposits. Presence of thick bed of dark grey mudstone beds (Fm) is represented as the flooding materials. Well-sorted pebble- to cobble conglomerates ( $\mathrm{Gm}$ facies) deposits from the bedload of gravelly river system. Sharp contact beds and clast-supported conglomerate reflect the formation of this facies association by high strength debris flows. So, FA7 is considered as the deposits of a debris flow-dominated braided system. Generally, these systems are observed in gravelly alluvial fan systems.

\section{DEPOSITIONAL PROCESS}

Five types of fluvial styles are recognized during the sedimentation period of the Siwalik Group in the Kankai River section. The earliest stage of the Siwalik sediment deposition began in a fine-grained meandering river system belonging to the FA1- facies association as described above. During this stage evidence of a long-term exposure of the flood plain and back swamp deposits is found. The second stage represented by the FA2 and FA3-facies associations is a fluvial environment with dominant assemblages of flood and crevasse splay sediment deposition. These facies associations indicate that the sedimentation took place in a flood flow-dominated meandering river systems. The third stage with the FA4 and FA5-facies associations is represented by deposits formed by a sandy braided river system as evidenced by the presence of thick-bedded, coarse- to very coarse-grained sandstone beds. During the fourth stage the fluvial system changed into a gravelly braided river system characterised by the FA6facies association, which is distinguished from previous facies mainly by abrupt increase in sediment grain size. Lastly in stage 5 , the debris flow-dominated braided river system was developed. FA7-facies association is characterised by poorly sorted boulder-sized and well-sorted gravel beds and pebbleand cobble-sized, massive gravel beds. The former were formed by debris flow, whereas the latter represent bedload current deposits. Such facies associations are generally found in an alluvial fan setting.

\section{PALEOHYDROLOGICAL CHARACTERISTICS}

Representative lithological columnar sections and their interpretation of the Siwalik Group along the Kankai River section have been clarified by Ulak (2009). The study is concentrated only in the south belt of the Siwalik Group of the Kankai River area, east Nepal Samples for grain size analysis to establish paleohydrology of the Siwalik Group were collected from the bottoms of the fining-upward succession of the complete fluvial cycles on a scale from several to tens metres. The bottom of the fining-upward succession is suitable sampling position for paleohydrological estimation but some of the sample collected from the middle part of the fining upward successions. Out sized clasts are observed in the bottoms of some successions, however, samples do not include such clasts. Sampling location, its stratigraphic position, and each columnar section are shown in Figures 1 and 2.

Each fining-upward succession generally comprises bedload beds of stratified sands and gravels at bottom and suspended load of muddy material at top. Measurement of bedload bed thickness and sampling position from the bottom of the finingupward cycles, and the description of sedimentary structures were performed for paleohydrological estimation (Fig. 2). Fifty seven samples are collected from eighteen sections ( $\mathrm{KC} 01$ to $\mathrm{KC} 18$ ) in this study.

\section{Grain size analyses}

Thin section method and a settling tube method were used for grain-size analyses. The consolidation of samples widely varied from strongly lithified to loosely packed. The thin section method is used for measurement of the grain size of the strongly lithified sand samples and applied to stratigraphic lower 30 samples from KC01a to KC09c covers the upper Member of the Lower Siwalik and lower Member of the Middle Siwalik and the settling tube method for the unconsolidated sand samples, applied to stratigraphic upper 27 samples from KC10a to KC218b, from middle Member of the Middle Siwalik to lower Member of the Upper Siwalik carried out. More than 200 of longest apparent grain dimension were measured in one thin section, and determined the mean of dimension, $50 \%$ dimension, and $95 \%$ of dimension, as mean diameter, and $95 \%$ of grain size distribution, respectively. The values of the grain size obtained by the thin section and settling tube methods are not in meaningful differences are not recognized.

Bedload in any stratigraphic records has variation in grain size. A considerable number of studies has been estimated the paleohydrology using various representative grain parameters. 
It is generally assumed that the largest size clast on the bed has primary control on grain resistance, and entrainment characteristics. Maizels (1983) reviewed the representative grain size in fluvial gravely deposits, and recommended the $95 \%$ of the whole grain size distribution $\left(D_{95}\right)$. Allen and Homewood (1984) adopted that mean grain size $\left(\mathrm{D}_{50}\right)$ for paleohydrologic reconstruction, but there was no hydraulic justification for its use. Then $\mathrm{D}_{95}$ of each sample is adopted for estimation in this study (Table 2).

It is impossible to apply the unique method for paleohydrologic estimation on the whole Siwalik succession, because of wide variation of consolidation and grain size of the group. From experimental work and data from natural streams, measures of stream competence can simply be functionally related to particle size where particles are larger than 5-8 $\mathrm{mm}$ in diameter (Maizels, 1983). Below this size, viscous forces begin to become effective rather than inertial forces, and also grain below this size can easily form visible-sized bedforms. Table 2 shows only KC18a and KC18b samples are gravelly larger than this criteria size, and other samples are sandy. Basically the method used by Allen and Homewood (1984) for sandy sediments, and Maning-Limerious method recommended by Maizels (1983) for gravely sediments. Ethridge and Schumm (1978) recommended the two methods for sandy fluvial system, based on the paleochannel dimension. Apparent sedimentary structures (bedforms) are observable in a whole succession along the Kankai River section, however, the measurement of channel dimension is frequently difficult. So, the method of Allen and Homewood (1984) adopted which restricts paleohydrologic values in terms of bedforms. The method of Allen and Homewood (1984) is originally for the tidal sediments, and Masuda and Nakayama (1988) and Nakayama (1997) slightly converted it for both tidal and the fluvial sediments, and adopted this converted method in this study. In Maning-Lemerious methods, the estimated slope gradient values calculated from the grain size is applied instead of actual measured values because of the outcrop limitation. The estimation methods in this paper needs simply grain size and flow depth.

\section{Paleoflow depth}

Thickness between the top of bedload beds and sampling horizon is used for paleoflow depth. Most of the samples were obtained from the bottoms of the fining-upward cycles, so that bedload thickness is frequently concordant with flow depth in this study. This is the extended application of the bankfull flow estimation in meandering channel (Ethridge and Schumm 1978; Bridge 1978).

Lateral accretion architecture are recognised in $\mathrm{KC} 01$. The estimation method of bankfull flow depth in meandering channel is directly applied to these three localities. Other fining-upward cycles in this study have no apparent evidence of deposits of meandering channel, however, any described columnar sections are the same order thickness of fining upward cycles ranging from several to tens meters. So bedload thickness in simple upward-fining cycle can be considered to roughly indicate the bankfull flow depth.

Ethridge and Schumm (1978) indicates the coefficient of 0.585/0.9 for convert from bedload thickness to paleoflow depth. However, the coefficient is not used because the estimation in this study applied to all fining-upwards may not have such preciseness. The decompacted thickness is not calculated because all our measured thickness are bedload sand and gravel parts in which the compaction must be negligible. Above these, there must be some imprecision for estimation of flow depth, however, the final estimated values must be sufficient to discuss the evolutional change of paleohydrology.

\section{Paleohydrology for sandy bedload}

The method by Allen and Homewood (1984) provides the depth-man velocities for the threshold of sediment movement $(U c r)$, ripple-dune transition $(U r d)$, and transition to upper plane bed from ripples and dunes (Uup) based on the flow depth and grain size:

$$
U_{c r}=\frac{u_{c r}}{\kappa} \ln \left(\frac{d}{e z_{0}}\right)
$$

Where, $U c r$ is the shear velocity for the threshold of sediment movement (Vanoni 1964; Yalin 1972), $k$ is von Karman's constant, $d$ is the flow depth in meter, and $z_{0}$ is the roughness length in meter. Values of and $z_{0}$ are 0.4 and 0.0004 used in this study, according to Allen and Homewood (1984). $U c r$ is calculated from the shear stress for threshold (Ucr) which are directly related to grain diameter (Miller et al. 1977). Similarly, Urd and Uup are obtained by following equations:

$$
\begin{aligned}
& U_{r d}=\frac{u_{r d}}{\kappa} \ln \left(\frac{d}{e z_{0}}\right) \\
& U_{u p}=\frac{u_{u p}}{\kappa} \ln \left(\frac{d}{e z_{0}}\right)
\end{aligned}
$$

Where, Urd is the shear velocity for ripple-dune transition (Vanoni 1964), and uup is the shear velocity for upper plane bed transition from ripples and dunes (Bagnold 1966). Other symbols are same in equation (1). The value of use as 0.4 in both equations, and use 0.0006 and 0.001 for $z_{0}$ in equations (2) and (3), respectively. 
Three velocity values are calculated on each sample, and then estimate the unique velocity value (V) based on these three values and bedform configurations. First, the relation between bedforms and bedding structures must be confirmed. Planar-cross bedding and trough-cross bedding are formed by accumulation of 2D dunes and 3D dunes, respectively. Ripple lamination is formed by ripples. Second, relation between grain size and bedform is also important. Relative small grains less than about $0.15 \mathrm{~mm}$ in diameter never form dunes, while relative coarse grains larger than about $0.8 \mathrm{~mm}$ in diameter never form ripples. Both ripples and dunes can occur of which grain diameter is between these sizes. Third, then we restrict the velocity range using bedform type, that is, 2D dunes and 3D dunes occur under the flow between Urd and Uup, and ripples occur under the flow between $U c r$ and Urd. Further, $2 \mathrm{D}$ dunes are formed in relative slower velocity of the range between Urd (or Ucr) and Uup, while 3D dunes are formed in relative faster velocity of this range. Each equation and its applicable grain range and bedform is explained in the note of Table 3. Paleochannel gradient for critical flow $\left(S_{c}\right)$ condition is also estimated:

$$
S_{c}=\frac{\tau_{c r}}{\gamma \cdot d_{c}}
$$

Where, $\gamma$ is the specific weight of water taken as $1000 \mathrm{~kg} /$ $\mathrm{m}^{3}, d$ is used for critical flow depth $\left(d_{c}\right)$.

\section{Paleodischarge for sandy bedload}

The simplest equation for discharge $(\mathrm{Q})$ is:

$$
Q=V A
$$

Where, $\mathrm{V}$ is mean velocity, and $\mathrm{A}$ is cross-sectional area of flow. However, since the channel width necessary for determining cross sectional area (A) difficult on ancient sediments outcropped in a limited area, other method of estimating discharge are useful. Estimation of the discharge is based on the depth and grain size for the sandy materials (Kellerhals 1967).

$$
Q=70.2 * d_{c}^{2} * D_{m}^{0}
$$

\section{Paleohydrology for gravelly bedload}

On the case of gravel clasts at high Reynolds number, the critical tractive force ( $=$ shear stress of threshold: $\left.\tau_{\mathrm{cr}}\right)$ is obtained using the following equation (Shields 1936, Graf 1971):

$$
\tau_{\mathrm{cr}}=0.056\left(\gamma_{s}-\gamma\right) \mathrm{D}
$$

Where, $\gamma_{s}$ is the specific weight of clast taken as $2650 \mathrm{~kg} /$ $\mathrm{m}^{3}$. D is the size of bed roughness element, for which $\mathrm{D}_{95}$ is used. Then channel gradient $\left(S_{c}\right)$ for critical flow condition is obtained from equations (4) and (7).

$$
S_{c}=\frac{0.092 D_{95}}{d_{c}}
$$

Paleoflow velocity for critical flow condition can be calculated according to the Manning-Limerinos equation:

$$
\bar{V}_{c}=\frac{\sqrt[3]{d_{c}^{2}}}{\sqrt{S_{c}}} \cdot \frac{1.16+2.0 \log \left(\frac{d_{c}}{D_{95}}\right)}{0.113 \sqrt[6]{d_{c}}}
$$

Where $V_{c}$ is the critical mean flow velocity, and adopted $V c$ as the unique velocity value $V$ in Table 3.

\section{Paleodischarge for gravelly bedload}

Determination of the paleodischarge of the sands and gravel deposits Manning-Limerinos equation (Maizels 1983) by equation 10 .

$$
Q=\frac{\overline{V_{c}}}{S_{c}}
$$

\section{RESULTS AND FINDINGS}

By using above mentioned formulae, estimation of the gradient, velocity and discharge are summarised in the Figure 3 , Tables 3 and 4. Measured slope gradient is varied from 6.67 $\mathrm{x} 10-5$ to $2.97 \times 10-4 \mathrm{~m} / \mathrm{m}$, velocity is ranged from 0.19 to 5.31 $\mathrm{m} / \mathrm{s}$ whereas the paleodischarge showed the ranges of 101 to $104 \mathrm{~m}^{3} / \mathrm{s}$.

\section{EVOLUTION OF FLUVIAL SYSTEM AND ESTIMATED PALEOHYDROLOGY}

Figure 3 indicates the reconstruction of paleohydrology within the stratigraphic framework. Both paleoflow velocity, paleochannel gradient and paleodischarge are gradually increased along the stratigraphic upward. The method in this study is applied the stratigraphic range between the Lower and Upper Siwalik.

Evolutional pattern of five stages which are from meandering system (stage 1), flood flow-dominated meandering system (stage 2), sandy braided system (stage 3), gravelly braided system (stage 4) and lastly the debris-flow dominated gravelly braided system. The inception of stage land stage 5 were controlled by the activation of the Main Central Thrust (MCT) and Main Boundary Thrust (MBT) as well as Central Churia Thrust (CCT), respectively. Two drastic paleohydrologic changes in this study is coincide with the inception stage 3 and stage. That is, paleohydrologic change must reflect the southward progradation of thrust activities. Stage 2, stage 3, stage 4, and stage 5, were occurred at 9.9 Ma, 8.2 Ma, 2.5 Ma and $1.0 \mathrm{Ma}$, respectively.

The Siwalik Group indicated the coarsening-upward as a whole, which has been simply considered to reflect the upliftment Himalaya. However, this study indicates that the Siwalik sedimentation has also to be considered in the viewpoint of the proximity from the thrust-formed piedmont line. 
Table 3: Details of the paleohydrology of the Siwalik Group of the Kankai River section, east Nepal.

\begin{tabular}{|c|c|c|c|c|c|c|c|c|c|c|c|}
\hline \multirow{2}{*}{$\begin{array}{l}\text { Stratigraphic } \\
\text { Thickness (m) }\end{array}$} & \multirow{2}{*}{ Bedding } & \multicolumn{2}{|c|}{ Grain size } & \multicolumn{8}{|c|}{ Paleohydrolgical parameters } \\
\hline & & $D_{50}(\mathrm{~mm})$ & $D_{95}(\mathrm{~mm})$ & Depth (m) & Ucr $(\mathrm{m} / \mathrm{s})$ & $\operatorname{Urd}(\mathrm{m} / \mathrm{s})$ & $\operatorname{Upd}(\mathrm{m} / \mathrm{s})$ & $\mathbf{V}(\mathbf{m} / \mathbf{s})$ & Velocity $(\mathrm{m} / \mathrm{s})$ & Gradient (m/m) & Discharge $\left(\mathbf{m}^{3} / \mathbf{s}\right)$ \\
\hline \multicolumn{12}{|c|}{ Lower member of Upper Siwalik } \\
\hline 3270 & HB & 13.63 & 27.13 & 6.30 & $* * * *$ & $* * * *$ & $* * * *$ & 5.31 & 5.31 & $3.96 \mathrm{E}-04$ & $1.22 \mathrm{E}+04$ \\
\hline 3245 & $\mathrm{HB}$ & 8.41 & 18.67 & 4.30 & $* * * *$ & $* * * *$ & $* * * * *$ & 4.65 & 4.65 & 3.99E-04 & $1.16 \mathrm{E}+04$ \\
\hline 2356 & PB & 0.39 & 0.85 & 1.90 & 0.30 & 0.45 & 0.66 & ***** & 0.52 & $1.31 \mathrm{E}-04$ & $3.86 \mathrm{E}+02$ \\
\hline 2345 & TB & 0.72 & 1.53 & 1.10 & 0.32 & 3.27 & 0.79 & $* * * *$ & 1.61 & $3.18 \mathrm{E}-04$ & $1.03 \mathrm{E}+02$ \\
\hline \multicolumn{12}{|c|}{ Upper member of Middle Siwalik } \\
\hline 1880 & TВ & 2.06 & 5.671 & 3.70 & 0.68 & 0.65 & 1.35 & $* * * *$ & 1.12 & $2.97 \mathrm{E}-04$ & $1.92 \mathrm{E}+03$ \\
\hline 1860 & TB & 0.20 & 0.405 & 3.20 & 0.27 & 0.27 & 0.53 & $* * * *$ & 0.45 & $5.62 \mathrm{E}-05$ & $1.35 \mathrm{E}+03$ \\
\hline 1845 & TB & 0.51 & 1.234 & 4.90 & 0.36 & 0.61 & 0.93 & ***** & 0.82 & $6.12 \mathrm{E}-05$ & $3.79 \mathrm{E}+03$ \\
\hline 1460 & TB & 0.15 & 0.268 & 2.70 & 0.25 & 0.18 & 0.33 & ***** & 0.28 & $5.93 \mathrm{E}-05$ & $9,01 \mathrm{E}+02$ \\
\hline 1445 & TB & 0.70 & 1.389 & 1.70 & 0.34 & 0.91 & 0.87 & ***** & 0.88 & $2.05 \mathrm{E}-04$ & $2.95 \mathrm{E}+02$ \\
\hline \multicolumn{12}{|c|}{ Middle member of Middle Siwalik } \\
\hline 1110 & TB & 0.30 & 0.592 & 6.10 & 0.30 & 1.05 & 0.74 & $* * * *$ & 0.84 & $3.1 \mathrm{E}-05$ & $6.42 \mathrm{E}+03$ \\
\hline 1105 & TB & \begin{tabular}{|l|}
0.61 \\
\end{tabular} & 1.203 & \begin{tabular}{|l|}
4.80 \\
\end{tabular} & \begin{tabular}{|l|}
0.38 \\
\end{tabular} & \begin{tabular}{|l|}
0.46 \\
\end{tabular} & \begin{tabular}{|l|}
0.77 \\
\end{tabular} & ***** & 0.67 & $6.7 \mathrm{E}-05$ & $2.95 \mathrm{E}+02$ \\
\hline 1098 & $\mathrm{RL}$ & \begin{tabular}{|l|l|}
0.16 \\
\end{tabular} & 0.302 & \begin{tabular}{|l|}
1.90 \\
\end{tabular} & 0.22 & 0.45 & 0.42 & ***** & 0.33 & 7.4E- 05 & $3.86 \mathrm{E}+02$ \\
\hline 1095 & $\mathrm{RL}$ & \begin{tabular}{|l|}
0.20 \\
\end{tabular} & 0.401 & \begin{tabular}{|l|}
0.90 \\
\end{tabular} & 0.22 & \begin{tabular}{|l|}
0.19 \\
\end{tabular} & \begin{tabular}{|l|}
0.40 \\
\end{tabular} & ***** & 0.20 & $1.9 \mathrm{E}-04$ & $6.38 \mathrm{E}+01$ \\
\hline 945 & TB & 0.81 & 1.678 & 2.70 & 0.39 & 0.75 & 1.04 & ***** & 0.82 & $1.4 \mathrm{E}-04$ & $9.01 \mathrm{E}+02$ \\
\hline 939 & PB & \begin{tabular}{|l|}
0.38 \\
\end{tabular} & 0.723 & 0.90 & 0.26 & 0.46 & \begin{tabular}{|l|}
0.54 \\
\end{tabular} & ***** & 0.49 & $2.7 \mathrm{E}-04$ & $6.38 \mathrm{E}+01$ \\
\hline 935 & TB & 0.22 & 0.405 & 1.80 & 0.25 & 0.20 & 0.37 & ***** & 0.32 & $1.0 \mathrm{E}-04$ & $3.39 \mathrm{E}+02$ \\
\hline 853 & PB & \begin{tabular}{|l|}
0.23 \\
\end{tabular} & 0.442 & \begin{tabular}{|l|}
2.90 \\
\end{tabular} & \begin{tabular}{|l|}
0.26 \\
\end{tabular} & \begin{tabular}{|l|}
0.80 \\
\end{tabular} & \begin{tabular}{|l|}
0.56 \\
\end{tabular} & $* * * *$ & 0.64 & $6.2 \mathrm{E}-05$ & $1.07 \mathrm{E}+03$ \\
\hline 851 & TB & \begin{tabular}{|l|}
0.63 \\
\end{tabular} & \begin{tabular}{|l|}
1.398 \\
\end{tabular} & \begin{tabular}{|l|}
3.90 \\
\end{tabular} & 0.35 & \begin{tabular}{|l|}
1.13 \\
\end{tabular} & \begin{tabular}{|l|}
0.99 \\
\end{tabular} & ***** & 1.04 & $7.4 \mathrm{E}-05$ & $2.18 \mathrm{E}+03$ \\
\hline 845 & PB & \begin{tabular}{|l|}
0.39 \\
\end{tabular} & 0.786 & \begin{tabular}{|l|}
1.40 \\
\end{tabular} & \begin{tabular}{|l|}
0.27 \\
\end{tabular} & \begin{tabular}{|l|}
0.17 \\
\end{tabular} & \begin{tabular}{|l|} 
\\
\end{tabular} & \begin{tabular}{|l|l}
$* * * * *$ \\
\end{tabular} & 0.32 & 1.6E-04 & $2.85 \mathrm{E}+02$ \\
\hline 840 & $\mathrm{~TB}$ & 0.63 & 1.398 & 3.90 & 0.35 & 1.13 & 0.99 & ***** & 1.04 & $7.4 \mathrm{E}-05$ & $2.18 \mathrm{E}+03$ \\
\hline 755 & TB & 0.32 & 0.612 & \begin{tabular}{|l|}
1.90 \\
\end{tabular} & 0.27 & \begin{tabular}{|l|l}
0.77 \\
\end{tabular} & 0.60 & ****** & 0.66 & $1.1 \mathrm{E}-04$ & $3.86 \mathrm{E}+02$ \\
\hline 752 & $\mathrm{RL}$ & 0.08 & 0.187 & 4.80 & 0.20 & 0.17 & 0.36 & $* * * *$ & 0.19 & $1.9 \mathrm{E}-04$ & $3.60 \mathrm{E}+03$ \\
\hline 750 & TB & \begin{tabular}{|l|}
0.10 \\
\end{tabular} & 0.208 & \begin{tabular}{|l|l|}
6.10 \\
\end{tabular} & \begin{tabular}{|l|}
0.23 \\
\end{tabular} & \begin{tabular}{|l|l|}
1.17 \\
\end{tabular} & \begin{tabular}{|l|} 
\\
\end{tabular} & ***** & 0.68 & $1.8 \mathrm{E}-05$ & $6.42 \mathrm{E}+03$ \\
\hline 745 & PB & \begin{tabular}{|l|l|}
0.18 \\
\end{tabular} & 0.387 & 2.50 & 0.25 & \begin{tabular}{|l|l|}
1.04 \\
\end{tabular} & \begin{tabular}{|l|}
0.49 \\
\end{tabular} & ***** & 0.86 & $6.8 \mathrm{E}-05$ & $7.48 \mathrm{E}+02$ \\
\hline 642 & TB & 0.15 & 0.298 & 0.80 & 0.19 & 0.56 & 0.33 & ***** & 0.41 & $1.6 \mathrm{E}-05$ & $4.81 \mathrm{E}+01$ \\
\hline 634 & $\mathrm{RL}$ & 0.16 & 0.301 & 1.30 & 0.20 & 0.40 & 0.38 & ***** & 0.30 & $1.0 \mathrm{E}-04$ & $1.54 \mathrm{E}+02$ \\
\hline 625 & TB & 0.35 & 0.676 & $\begin{array}{l}1.60 \\
\end{array}$ & 0.29 & 0.95 & \begin{tabular}{|l|}
0.60 \\
\end{tabular} & ***** & 0.72 & $1.6 \mathrm{E}-04$ & $2.55 \mathrm{E}+02$ \\
\hline \multicolumn{12}{|c|}{ Lower member of Middle Siwalik } \\
\hline 538 & TB & \begin{tabular}{|l|}
0.07 \\
\end{tabular} & 0.151 & \begin{tabular}{|l|}
3.20 \\
\end{tabular} & \begin{tabular}{|l|}
0.19 \\
\end{tabular} & \begin{tabular}{|l|}
0.81 \\
\end{tabular} & \begin{tabular}{|l|} 
\\
\end{tabular} & $* * * *$ & 0.64 & 2.81E-05 & $1.35 \mathrm{E}+03$ \\
\hline 535 & TB & \begin{tabular}{|l|l|}
0.24 \\
\end{tabular} & $\begin{array}{l}0.486 \\
\end{array}$ & 5.30 & \begin{tabular}{|l|l|}
0.29 \\
\end{tabular} & \begin{tabular}{|l|}
0.67 \\
\end{tabular} & 0.65 & ***** & 0.66 & 3.40E-05 & $4.58 \mathrm{E}+03$ \\
\hline 532 & RL & \begin{tabular}{|l|} 
\\
\end{tabular} & 0.289 & 2.60 & 0.23 & 0.65 & \begin{tabular}{|l|l|} 
\\
\end{tabular} & $* * * *$ & 0.44 & 5.38E-05 & $6.38 \mathrm{E}+01$ \\
\hline 474 & $\mathrm{RL}$ & 0.03 & 0.427 & 3.20 & 0.14 & 0.29 & 0.20 & $* * * *$ & 0.22 & $1.56 \mathrm{E}-05$ & $1.35 \mathrm{E}+03$ \\
\hline 468 & TB & \begin{tabular}{|l|}
0.19 \\
\end{tabular} & 0.389 & 1.20 & 0.22 & 0.65 & 0.40 & \begin{tabular}{|l|l}
$* * * *$ \\
\end{tabular} & 0.57 & $1.33 \mathrm{E}-04$ & $1.27 \mathrm{E}+02$ \\
\hline 465 & PB & 0.14 & 0.278 & 1.70 & 0.14 & 0.62 & 0.39 & $* * * *$ & 0.54 & $3.53 \mathrm{E}-05$ & $2.95 \mathrm{E}+02$ \\
\hline 310 & $\mathrm{RL}$ & \begin{tabular}{|l|l|}
0.14 \\
\end{tabular} & 0.287 & \begin{tabular}{|l|}
2.10 \\
\end{tabular} & \begin{tabular}{|l|}
0.22 \\
\end{tabular} & \begin{tabular}{|l|}
0.57 \\
\end{tabular} & 0.41 & ***** & 0.40 & 6.67E-05 & $4.91 \mathrm{E}+02$ \\
\hline 305 & $\mathrm{RL}$ & \begin{tabular}{|l|l|}
0.18 \\
\end{tabular} & 0.356 & 2.30 & 0.20 & $\begin{array}{ll}0.69 \\
\end{array}$ & \begin{tabular}{|l|l|}
0.47 \\
\end{tabular} & ***** & 0.44 & $4.78 \mathrm{E}-05$ & $6.12 \mathrm{E}+02$ \\
\hline \multicolumn{12}{|c|}{ Upper member of Lower Siwalik } \\
\hline 210 & $\mathrm{~TB}$ & 0.41 & 0.808 & 5.10 & 0.33 & 0.85 & 0.84 & $* * * *$ & 0.67 & $4.90 \mathrm{E}-05$ & $4.17 \mathrm{E}+03$ \\
\hline 208 & $\mathrm{RL}$ & 0.09 & 0.176 & 0.60 & 0.15 & 0.28 & 0.23 & $* * * * *$ & 0.22 & $1.50 \mathrm{E}-04$ & $2.40 \mathrm{E}+01$ \\
\hline 207 & $\mathrm{pb}$ & 0.19 & 0.389 & 1.40 & 0.23 & 0.47 & 0.43 & $* * * *$ & 0.36 & $1.21 \mathrm{E}-04$ & $1.85 \mathrm{E}+02$ \\
\hline 205 & TB & 0.25 & 0.459 & 5.20 & 0.29 & 0.90 & 0.65 & $* * * *$ & 0.53 & $3.65 \mathrm{E}-05$ & $4.37 \mathrm{E}+03$ \\
\hline 203 & TB & 0.28 & 0.561 & 2.90 & 0.27 & 1.10 & 0.62 & $* * * *$ & 0.50 & $6.55 \mathrm{E}-05$ & $1.07 \mathrm{E}+03$ \\
\hline 198 & TB & 0.28 & 0.519 & 1.40 & 0.25 & 0.50 & 0.52 & ***** & 0.43 & $1.35 \mathrm{E}-04$ & $1.85 \mathrm{E}+02$ \\
\hline 195 & $\mathrm{RL}$ & 0.20 & 0.390 & 1.30 & 0.23 & 0.58 & 0.43 & ***** & 0.40 & $1.31 \mathrm{E}-04$ & $2.95 \mathrm{E}+02$ \\
\hline 190 & TB & 0.11 & 0.204 & 1.50 & 1.90 & 0.64 & 0.33 & $* * * * *$ & 0.85 & $7.33 \mathrm{E}-04$ & $2.18 \mathrm{E}+02$ \\
\hline 188 & TB & 0.13 & 0.254 & 1.90 & 0.24 & 0.40 & 0.38 & $* * * *$ & 0.33 & $8.42 \mathrm{E}-05$ & $3.86 \mathrm{E}+02$ \\
\hline 185 & TB & 0.20 & 0.401 & 2.40 & 0.26 & 0.84 & 0.50 & $* * * *$ & 0.42 & $7.50 \mathrm{E}-05$ & $6.38 \mathrm{E}+01$ \\
\hline 172 & $\mathrm{RL}$ & 0.14 & 0.278 & 0.90 & 0.18 & 0.54 & 0.33 & $* * * *$ & 0.36 & $1.33 \mathrm{E}-04$ & $6.38 \mathrm{E}+01$ \\
\hline 165 & PB & 0.23 & 0.445 & 5.20 & 0.28 & 0.63 & 0.63 & $* * * *$ & 0.63 & $3.46 \mathrm{E}-05$ & $4.37 \mathrm{E}+03$ \\
\hline 160 & $\mathrm{RL}$ & \begin{tabular}{|l|}
0.10 \\
\end{tabular} & 0.221 & \begin{tabular}{|l|l|}
0.70 \\
\end{tabular} & \begin{tabular}{|l|}
0.17 \\
\end{tabular} & \begin{tabular}{|l|}
0.52 \\
\end{tabular} & \begin{tabular}{|l|}
0.26 \\
\end{tabular} & ***** & 0.34 & $1.57 \mathrm{E}-04$ & $3.48 \mathrm{E}+01$ \\
\hline 138 & $\mathrm{RL}$ & 0.15 & 0.301 & 0.90 & 0.21 & 0.56 & \begin{tabular}{|l|}
0.34 \\
\end{tabular} & ***** & 0.39 & $1.77 \mathrm{E}-04$ & $6.38 \mathrm{E}+01$ \\
\hline 134 & TB & 0.32 & 0.656 & \begin{tabular}{|l|}
3.10 \\
\end{tabular} & 0.30 & 0.46 & \begin{tabular}{|l|} 
\\
\end{tabular} & ***** & 0.53 & 7.42E-05 & $1.85 \mathrm{E}+02$ \\
\hline 130 & TB & \begin{tabular}{|l|}
0.34 \\
\end{tabular} & \begin{tabular}{|l|}
0.659 \\
\end{tabular} & \begin{tabular}{|l|}
4.10 \\
\end{tabular} & \begin{tabular}{|l|}
0.31 \\
\end{tabular} & \begin{tabular}{|l|}
0.51 \\
\end{tabular} & \begin{tabular}{|l|}
0.74 \\
\end{tabular} & ***** & 0.59 & 5.61E-05 & $2.47 \mathrm{E}+03$ \\
\hline 112 & $\mathrm{RL}$ & $\begin{array}{ll}0.05 \\
\end{array}$ & \begin{tabular}{|l|l|}
0.111 \\
\end{tabular} & 0.80 & \begin{tabular}{|l|l|}
0.14 \\
\end{tabular} & \begin{tabular}{|l|l|}
0.59 \\
\end{tabular} & \begin{tabular}{|l|}
0.19 \\
\end{tabular} & ***** & 0.36 & \begin{tabular}{|l}
$8.75 \mathrm{E}-05$ \\
\end{tabular} & $4.80 \mathrm{E}+01$ \\
\hline 108 & $\mathrm{RL}$ & 0.26 & 0.523 & 1.10 & 0.23 & 0.49 & 0.47 & $* * * *$ & 0.36 & $1.63 \mathrm{E}-04$ & $1.03 \mathrm{E}+02$ \\
\hline 105 & $\mathrm{RL}$ & 0.11 & 0.243 & 1.50 & 0.19 & 0.64 & 0.33 & ***** & 0.42 & $7.33 \mathrm{E}-05$ & $4.80 \mathrm{E}+01$ \\
\hline 75 & RL & 0.07 & 0.123 & \begin{tabular}{|l|} 
\\
\end{tabular} & \begin{tabular}{|l|l|}
0.14 \\
\end{tabular} & 0.58 & 0.21 & ***** & 0.36 & 1.14E-04 & 3.48E +01 \\
\hline 65 & RL & 0.08 & 0.154 & 0.80 & 0.16 & 0.57 & 0.25 & ***** & 0.36 & $1.12 \mathrm{E}-04$ & $4.80 \mathrm{E}+01$ \\
\hline 58 & RL & \begin{tabular}{|l|}
0.10 \\
\end{tabular} & 0.203 & \begin{tabular}{|l|}
1.50 \\
\end{tabular} & \begin{tabular}{|l|}
0.18 \\
\end{tabular} & \begin{tabular}{|l|}
0.67 \\
\end{tabular} & 0.31 & $* * * *$ & 0.43 & 6.67E-05 & $2.18 \mathrm{E}+02$ \\
\hline
\end{tabular}




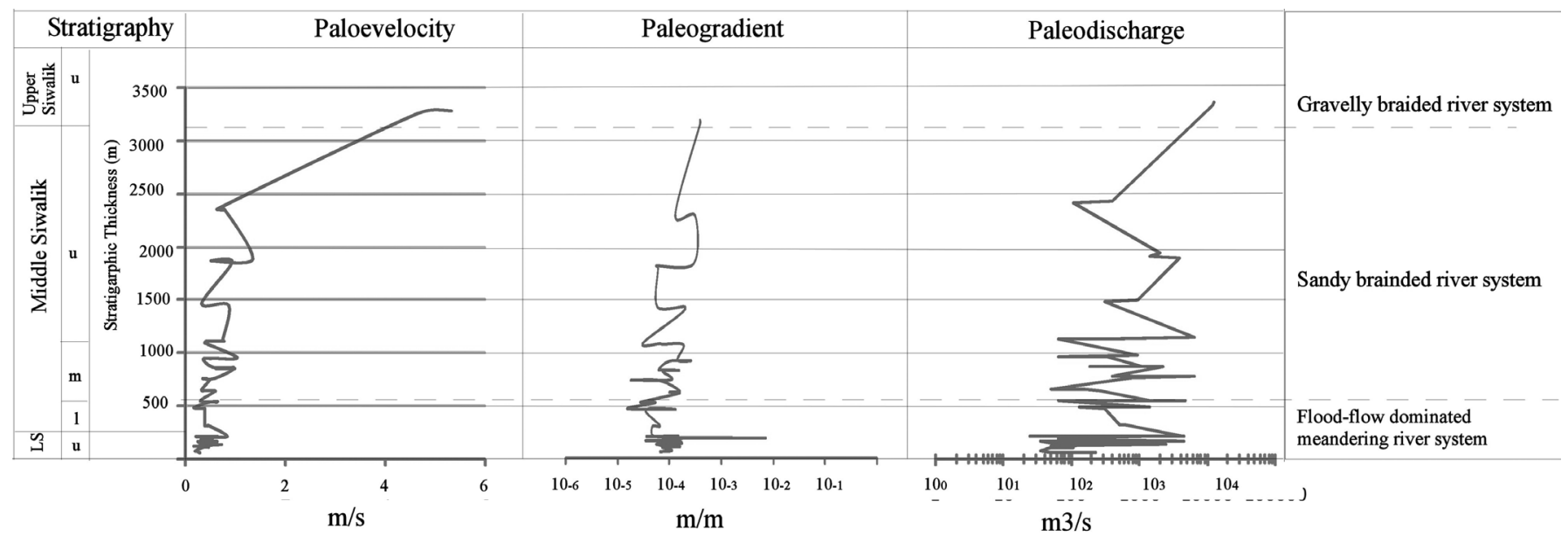

Fig. 3: Stratigraphic change in paleohydrological estimations in the Kankai River section, east Nepal.

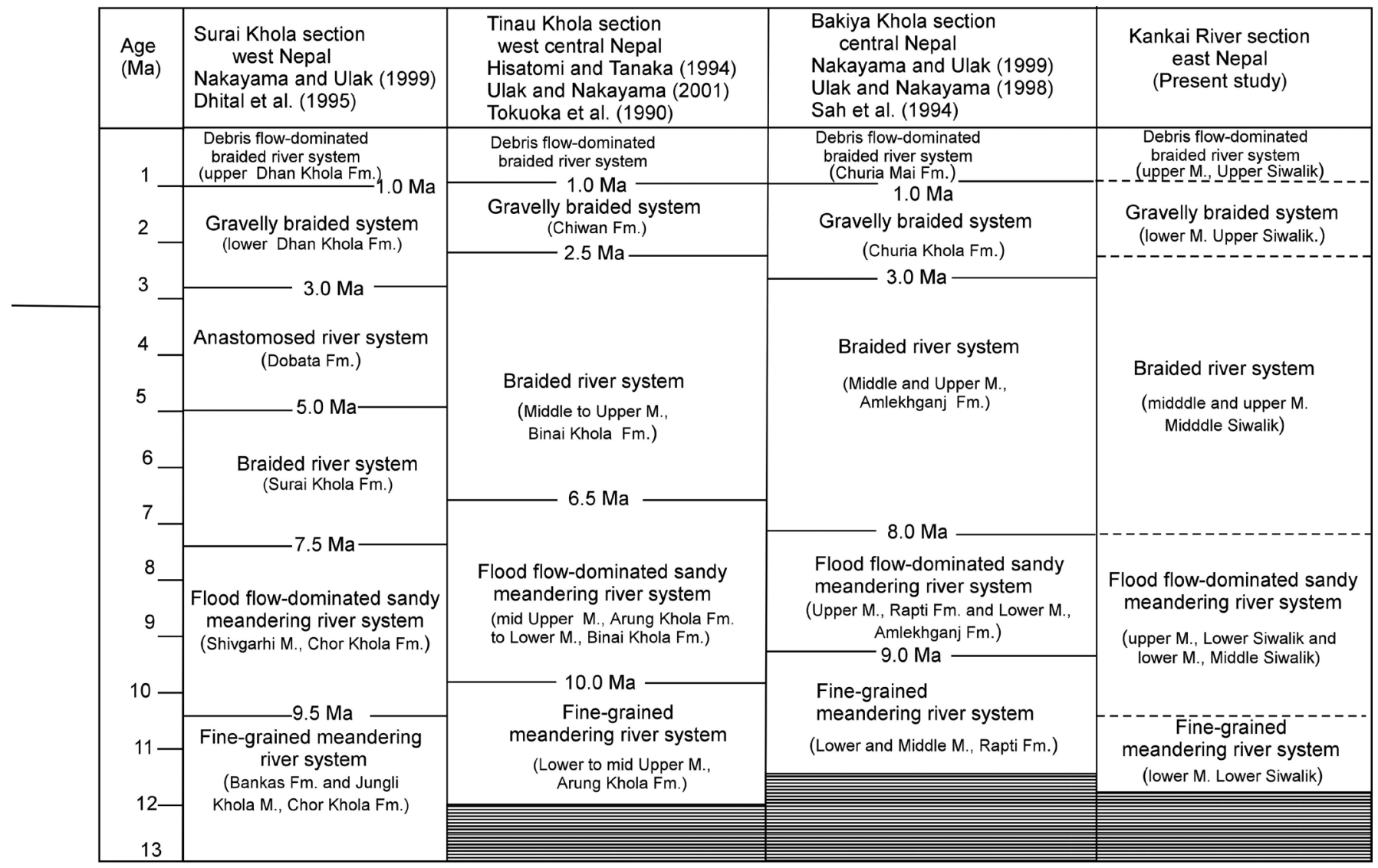

Fm.- Formation; M.-Member

Fig. 4: Relation between the reconstruction of paleohydrology and evolution of the fluvial system.

\section{DISCUSSION}

Periods of changes in fluvial system along the Kankai River section cannot be estimated due to lack of the paleomagnetic age. The flood flow-dominated meandering system was occurred at $10.5 \mathrm{Ma}$ in the Bakiya Khola section (central Nepal, Nakayama and Ulak 1999), 9.9 Ma in the Tinau Khola section (west-central Nepal; Ulak and Nakayama 2001) and 9.5 Ma in the Surai Khola section (west Nepal; Nakayama and Ulak 1999). General trend for development of the flood flow- dominated meandering system shows in the eastern Nepal at first so it is assumed that the evolution of the flood flowdominated meandering system along the Kankai River section before 10.5 Ma (Fig. 4).

The change from meandering to braided river system occurred at 9.0 Ma, 8.2 Ma and 6.5 Ma in the Bakiya Khola (central Nepal; Nakayama and Ulak 1999), Tinau Khola section (west-central Nepal; Ulak and Nakayama 2001) and Surai Khola section (west Nepal; Nakayama and Ulak 1999). 
Table 4: Estimated paleohydrological values and its relation to evolution of the fluvial styles in Siwalik basin.

\begin{tabular}{|c|c|c|c|c|c|c|c|c|c|c|c|}
\hline \multirow{2}{*}{ Stratigrahy } & \multicolumn{4}{|c|}{ Grain size (mm) } & \multirow{2}{*}{\multicolumn{2}{|c|}{$\begin{array}{c}\text { Velocity }(\mathrm{m} / \mathrm{s}) \\
(\mathrm{V})\end{array}$}} & \multirow{2}{*}{\multicolumn{2}{|c|}{$\begin{array}{c}\text { Gradient (m/m) } \\
(\mathrm{S}) \\
\end{array}$}} & \multirow{2}{*}{\multicolumn{2}{|c|}{$\begin{array}{c}\text { Discharge }\left(\mathbf{m}^{3} / \mathbf{s}\right) \\
(\mathrm{Q})\end{array}$}} & \multirow[t]{3}{*}{ Fluvial system } \\
\hline & \multicolumn{2}{|l|}{$\left(D_{m}\right)$} & \multicolumn{2}{|c|}{$\left(\mathrm{D}_{95}\right)$} & & & & & & & \\
\hline \multicolumn{11}{|l|}{$\begin{array}{l}\text { Upper } \\
\text { Siwalik }\end{array}$} & \\
\hline $\begin{array}{l}\text { Lower } \\
\text { member }\end{array}$ & 0.72 & 13.63 & 0.85 & 27.129 & \#REF! & 5.31 & $1.31 \mathrm{E}-04$ & $3.96 \mathrm{E}-04$ & $1.03 \mathrm{E}+02$ & $1.22 \mathrm{E}+04$ & $\begin{array}{l}\text { Gravelly } \\
\text { braided system }\end{array}$ \\
\hline \multicolumn{12}{|l|}{$\begin{array}{l}\text { Middle } \\
\text { Siwalik }\end{array}$} \\
\hline $\begin{array}{l}\text { Upper } \\
\text { member }\end{array}$ & 0.15 & 2.06 & 0.27 & 5.67 & 0.28 & 1.12 & $2.97 \mathrm{E}-04$ & $2.06 \mathrm{E}-04$ & $9,01 \times 102$ & $3.79 \times 103$ & $\begin{array}{l}\text { Sandy } \\
\text { braided system }\end{array}$ \\
\hline $\begin{array}{l}\text { Middle } \\
\text { member }\end{array}$ & 0.08 & 0.81 & 0.30 & 1.68 & 0.19 & 1.04 & $7.36 \mathrm{E}-05$ & $2.68 \mathrm{E}-04$ & $6.38 \mathrm{E}+01$ & $6.42 \mathrm{E}+03$ & \\
\hline $\begin{array}{l}\text { Lower } \\
\text { member }\end{array}$ & 0.03 & 0.24 & 0.15 & 0.48 & 0.22 & 0.66 & $6.66 \mathrm{E}-05$ & $1.33 \mathrm{E}-04$ & $6.38 \mathrm{E}+01$ & $4.37 \mathrm{E}+03$ & $\begin{array}{l}\text { Flood flow dominated } \\
\text { meandering system }\end{array}$ \\
\hline \multicolumn{12}{|l|}{$\begin{array}{l}\text { Lower } \\
\text { Siwalik }\end{array}$} \\
\hline $\begin{array}{l}\text { Upper } \\
\text { member }\end{array}$ & 0.05 & 0.41 & 0.11 & 0.80 & 0.22 & 0.85 & $8.75 \mathrm{E}-05$ & $1.33 \mathrm{E}-04$ & $2.40 \mathrm{E}+10$ & $4.58 \mathrm{E}+03$ & $\begin{array}{l}\text { Flood flow dominated } \\
\text { meandering system }\end{array}$ \\
\hline
\end{tabular}

The development of the braided river system may be occurred during 8.2 to $6.5 \mathrm{Ma}$ in the Kankai River section. The start of gravelly fluvial system begins $3.0 \mathrm{Ma}, 2.5 \mathrm{Ma}$, and $2.5 \mathrm{Ma}$ in the Bakiya Khola (Nakayama and Ulak 1999), Tinau Khola (Ulak and Nakayama 2001) and Surai Khola (Nakayama and Ulak 1999) sections, respectively. In the Kankai River section, the gravelly braided river system developed during 2.5 to 3.0 Ma. The estimated values of the paleohydrology in Kankai River section shows progressively increasing from lower to upper startigraphic units like other sections of the Nepal Himalaya (Ulak 2009; Ulak and Nakayama 2002; Ulak and Nakayama 2003).

The estimation method in this study covers with both sandy and gravelly sediments, and also applicable to the outcrops with the limited lateral-dimension. Further, the method can analyse the flow constitution using the multiple samples from a fining-upward cycle.

\section{CONCLUSIONS}

Seven types of facies associations are recognized in rocks of the Siwalik Group in Kankai River section, east Nepal. These recognized facies associations are closely related to the lithostratigraphic units. The sediments of the lower member of the Lower Siwalik are products of a fine-grained meandering system. The upper member of the Lower Siwalik was formed by the flood flow-dominated meandering system. In contrast, the Middle Siwalik is interpreted to result from deposits by a sandy meandering, deep sandy braided, and the shallow sandy braided systems, in lithologically ascending order. The sediments of the lower member of the Upper Siwalik were deposited by the gravelly braided system, whereas those of the upper member owe to the debris flow-dominated braided system.

The change in fluvial style from meandering to braided system one may be intimately related to the onset of Asian Monsoon and the uplift of the Himalayan-Tibetan Plateau Range (Ulak and Nakayama1998; Nakayama and Ulak 1999, 2001). Sedimentation of the Siwalik Group is the result of the collision of the Indian and Eurasian plate. Due to the development of the Main Central Thrust (MCT), Main Boundary Thrust (MBT), and Main Frontal Thrust (MFT) ot Frontal Churia Thrust (FCT) as well as Central Churia Thrust (CCT) upliftment of the north part started to deposition in the Siwalik basin.

The paleohydrological estimations for the Siwalik Group in Kankai River section gradually increase values from Lower to Upper Siwaliks. Paleochannel gradient varies from $6.67 \times 10^{-5}$ to $2.97 \times 10^{-4} \mathrm{~m} / \mathrm{m}$, paleovelocity ranges from $0.19 \mathrm{~m} / \mathrm{s}$ to $5.31 \mathrm{~m} / \mathrm{s}$ and paleodischarge changes from and $10^{1}$ to $10^{4} \mathrm{~m}^{3} / \mathrm{s}$. These estimations suggest that fluvial systems grew progressively larger due to southward progradation of thrust activity. The estimation method in this study is wide applicable, and suitable for analysing the evolutional change of fluvial system.

\section{ACKNOWLEDGEMENTS}

We would like to express our gratitude to Prof. V. Dangol, Prof. Prakash Chandra Adhikari and Prof. Lalu Prasad Paudel (Tribhuvan University, Nepal) for their valuable suggestions on the manuscript. 


\section{REFERENCES}

Allen, P. A. and Homewood, P., 1984, Evolution and mechanics of a Miocene tidal sandwave. Sedimentology, v. 31, pp. 63-81.

Auden, J. B., 1935, Traverses in the Himalaya. Rec. Geol. Surv. India, v. 69(2), pp. 123-167.

Bagnold, R. A., 1966, An approach to the sediment transport problem from general physics. Professional Paper of US Geol. Survey, v. 422-I, pp. 11-I37.

Bridge, J. S., 1978, Paleohydraulic interpretation using mathematical models of contemporary flow and sedimentation meandering channels. In Fluvial Sedimentology, (ed. A. D. Miall), Canadian Soc. Petroleum Geol., Memoir no. 5, pp. 723-742.

Corvinus, G. and Nanda, A. C., 1994, Stratigraphy and palaeontology of the Siwalik Group of the Surai Khola and Rato Khola in Nepal. N. J. Geol. Palaeont. Abh., 191, Stuttgart, Marz, pp. $25-$ 68.

Dhital, M. R., Gajurel, A. P., Pathak, D., Paudel, L. P., and Kizaki, K., 1995, Geology and structure of the Siwaliks and Lesser Himalaya in the Surai Khola-Bardanda area, mid Western Nepal. Bull. Dept. Geol., Tribhuvan Univ., v. 4, Sp. Issue, pp. 1-70.

Ethridge, F. G. and Schumm, S. H., 1978, Reconstructing paleochannel morphologic and flow characteristics: methodology, limitations and assessment. In Fluvial Sedimentology, (ed A. D. Miall), Canadian Soc. Petroleum Geol., Memoir no. 5, pp. 703-721.

Glennie, K. W. and Ziegler, M. A., 1964, The Siwaliks formation of Nepal. International Geol. Congr., 22 Sess. Rep. Pt., 25, pp. 82-95.

Graf, W. H., 1971, Hydraulics of Sediment Transport. New York: Siwalik Group in the foothill of the Nepal Himalaya, Sedmento. Geol., v. 125, pp. 205-224.

Hagen, T., 1969, Report on the Geological Survey of Nepal (preliminary reconnaissance). Denkschr. Schweiz. naturf. Gesell., v. 86(1), pp. 1-185.

Hisatomi, K. and Tanaka, S., 1994, Climatic and environmental changes at 9 and $7.5 \mathrm{Ma}$ in the Churia (Siwalik) Group, westcentral Nepal. Him. Geol. v. 15, pp. 161-180.

Kellerhals, R., 1967, Stable channels with gravel-paved beds. Jour. Waterways Harbors Div., Ammerican Soc., civil Engineers, v. 93, pp. 63-84.

Khan, I. A., Bridge, J. S., Kappelman, J. and Wilson, R., 1997, Evolution of Miocene fluvial environments, eastern Potwar Plateau, northern Pakistan. Sedimentol, v. 44, pp. 221-251.

Miall, A. D., 1996, The Geology of Fluvial Deposits Springer-Verlag Berlin $582 \mathrm{p}$.

Miller, W. J., Mccave, I. N. and Komar, P. D., 1977, Threshold of sediment motion under unidirectional currents. Sedimentology, v. 34, pp. 507-527.

Maizels, J. K., 1983, Paleovelocity and paleodischarge determination for coarse gravel deposits. In Background to Paleohydrology (ed. K. J. Gregory), pp. 103-139. John Wiley, New York.

Masuda, F. and Nakayama, N., 1988, Calculation of paleotidal current velocity. Jour. Sedimentol. Soc. Japan, v. 29, pp. 1-8 (in Japanese with English abstract).

Nakajima, T., 1982, Sedimentology and Uranium prospecting of the Siwaliks in western Nepal. Bull. Geol. Surv. Japan, v. 33(12), pp. 593-617.

Nakayama, K., 1997, Unidirectional to bidirectional subtidal sandwaves influenced by gradually decreasing steady flow velocity. Geol. Mag., v. 134, pp. 557-661.

Nakayama, K. and Ulak, P. D., 1999, Evolution of fluvial style in the Siwalik Group in the foothill of the Nepal Himalaya, Sedmento.
Geol., v. 125, pp. 205-224.

Parkash, B., Sharma, R. P. and Roy, A. K., 1980, The Siwalik Group (molasse) sediments shed by collision of continental plates. Sed. Geol., v. 25, pp. 127-159.

Parkash, B., Sharma, R. P. and Roy, A. K., 1980, The Siwalik Group (molasse) sediments shed by collision of continental plates. Sed. Geol., v. 25, pp. 127-159.

Sah, R. B., Ulak, P. D., Gajurel, A. P., and Rimal, L. N., 1994, Lithostratigrphy of Siwalik sediments of Amlekhganj-Hetauda area, sub-Himalaya of Nepal. Him. Geol., v. 15, pp. 37-48.

Shields, A., 1936, Anwendung der Ahnlichkeitsmechanik und der Turbulenzforschung auf die Geschiebebewegung: Mitteilungen der Preuss. Berlin: Versuchanst Wasserbau Schiffbau, 26 p.

Tokuoka, T., Takayasu, K., Yoshida, M., and Hisatomi, K., 1986, The Churia (Siwalik) Group of the Arung Khola area, west-central Nepal. Mem. Fac. Sci. Shimane Univ., v. 22, pp. 135-210.

Ulak, P. D. and Nakayama, K., 1998, Lithosratigraphy and evolution of the fluvial style in the Siwalik Group in the Hetauda-Bakiya Khola area, Central Nepal. Bull. Dept. Geol., v. 6, pp. 1-14.

Ulak, P. D. and Nakayama, K., 2001, Neogene fluvial systems in the Siwalik Group along the Tinau Khola section, west-central Nepal Himalya. Jour. Nepal Geol. Soc., v. 25, pp. 111-122.

Ulak, P. D. and Nakayama, K., 2002, Palaeohydrology of the Neogene Siwalik Group along the Bakiya Khola section, central Nepal. Him. Geol., v. 24(1), pp. 23-34.

Ulak, P. D., 2001, Paleohydrology of the Siwalik Group, Surai Khola area along Kalakate-Bhalubang section, west Nepal. Bull. Dept. Geol., Tribhuvan Univ., Nepal, v. 8, pp. 49-60.

Ulak, P. D., 2002, Paleohydrology of the Siwalik Group along the Bakiya Khola section. Central Nepal Himalaya. Jour. Nepal Geol. Soc., v. 26, pp. 49-58.

Ulak, P. D. and Nakayama, K., 2003, Palaeohydrology of the Neogene Siwalik Group along the Bakiya Khola section, central Nepal. Him. Geol., v. 24(1), pp. 23-34.

Ulak, P. D., 2004, Evolution of fluvial system in Siwalik Group of Chatara-Barahakshetra area, East Nepal Himalaya. Jour. Nepal Geol. Soc., v. 30, pp. 67-74.

Ulak, P. D., 2006, Paleohydrological reconstruction of molasses sediments from the Siwalik Group along Surai Khola section West Nepal Himalaya.. Jour. Nepal Geol. Soc., .v. 31, pp. $33-42$.

Ulak, P. D., 2009, Lithostratigraphy and late cenozoic fluvial styles of Siwalik Group along Kankai River section, east Nepal Himalaya. Bull. Central Department of Geology, v. 12, pp. 6374.

Ulak, P. D., 2009, Paleohydrological Reconstruction of the Siwalik Group along the Tinau Khola Section, west-central Nepal Himalaya, Jour. Nepal Geol. Soc., v. 39, pp. 23-32.

Vanoni, V. A., 1964, Factors determining bedforms in alluvial channels. Proc. American Soc. Civil Eng. v. 100, pp. 363-377.

Willis, B., 1993, Evolution of Miocene fluvial systems in the Himalayan foredeep through a two kilometer-thick succession in northern Pakistan. Sed. Geol., v. 88, pp. 77-121.

Yalin, M. S., 1972, Mechanics of Sediment Transport. New York: Pergamon Press, 290 p.

Yoshida, M. and Arita, K., 1982, On the Siwaliks observed along some routes in Central Nepal. Jour. Nepal Geol. Soc., v. 2, Sp. Issue, pp. 59-66.

Zaleha, M. J., 1997, Fluvial and lacustrine paleoenvironments of the Miocene Siwalik Group, northern Pakistan. Sedimentology, v. 44, pp. 349-368. 
